\title{
THE CRIMINAL LAW POWER: A MOVE TOWARDS FUNCTIONAL CONCURRENCY?
}

\author{
L. M. LEIGH*
}

In Canada, as in most Federal systems, a conflict of values, represented on the one hand by the federal authority and on the other by state authority results in a continual state of tension. Demands made upon the federal authority, perhaps not perceived in character or extent at the time of federation, require increasing intervention in all aspects of national life. The consequent arrogation of authority can only occur at the expense of provincial powers. At the same time, there is a continued interest, now clearly evident, in the survival and perhaps the enhancement of provincial powers. The problem of balance is a hardy perennial, the task of compromise is rarely simple, and the solution seldom gives entire satisfaction. To some extent, the problems can be minimized at a political level. Frequently, the task of arriving at a viable solution devolves upon the courts.

The implications for federalism in the enhancement or diminution of certain legislative powers have generally been recognized by the courts. An example is the power to legislate in relation to trade and commerce, the centralizing potential of which was early curtailed in Canada in the interests of preserving provincial autonomy, ${ }^{1}$ a mode of thought which is again fashionable. ${ }^{2}$ The centralizing potential of the criminal law power was also early recognized, ${ }^{3}$ and as with the commerce power, $a$ priori limits were set to its sweep. ${ }^{4}$ Yet the theoretical barriers have not inhibited federal power so rigidly, and the result has been in part that the Federal Parliament has been able to prohibit where it could not regulate. ${ }^{5}$ Furthermore, and as a necessary corollary, it has occupied fields in which otherwise the provinces might have legislated. ${ }^{6}$ In some cases, an extended view of the criminal law power has resulted in the denial of a provincial aspect where one might otherwise have been thought to exist. Yet the general impression which one derives from an examination of the reported cases has been one of judicial conservatism. Areas have been reserved to the provinces; provincial autonomy has been safeguarded to a considerable extent. In the field of road traffic indeed, for functional purposes, there now exists virtually a concurrent criminal law power. ${ }^{7}$ In this area at least, considerable flexibility in constitutional adjudication has been preserved.

* L. M. Leigh, B.A., LL.B. (Alta.), Lecturer in Law, London School of Economics and Political Science.

1 Smith, The Commerce Power in Canada and the United States (1963), c. 1.

2 e.g., Reg. v. Campbell (1964), 46 D.L.R. (2d) 83 (Porter, C. J. O., and Kelly, J. A., dissenting)

3 A.G. of Ontario v. Reciprocal Insurers, [1924] A.C. 328.

4 In re Board of Commerce Act 1919, [1922] 1 A.C. 191.

5 Compare Reg. v. Campbell (ante, n. 2) with A.G. of Ontario v. Reciprocal Insurers (ante, n. 3) and A.G. of Canada v. A.G. of Alberta, [1916] 1 A.C. 588.

6 e.g., the field of restraints on resale price maintenance.

7 And this despite the fact that the provincial criminal law power is admittedly derivative and formally can only be used to enforce provincial legislation otherwise valid. See Rex. v. Nat Bell Liquors Ltd., [1922] 2 A.C. 128; Quong Wing v. The King (1914), 49 S.C.R. 440 . 
In this essay it is proposed to examine the courts' attitudes towards the criminal law power with a view to determining some of the implications for Canadian federalism flowing therefrom. In some respects the enquiry is unique. Alone of the major federal systems in the common law world, Canada has vested exclusive power to legislate in relation to the criminal law with the federal parliament." In the course of the enquiry, it will be necessary to consider the past as well as the present in order properly to evaluate the present trend of decision.

\section{THE EARLY CONSTRUCTION OF THE CRIMINAL LAW POWER}

By sec. 91 (27) of the British North America Act, 1867, Parliament is empowered to make laws in relation to the criminal law and procedure in relation to criminal matters, but not in relation to the constitution of courts of criminal jurisdiction. It must, of course, be recognized that Parliament is not the sole legislative body having authority to enact criminal laws. The provinces can competently do so under sec. 92 (15) of the Act. Provincial competence is essentially derivative, being restricted to the "Imposition of Punishment by Fine, Penalty or Imprisonment for enforcing any law of the Province made in relation to any Matters coming within any of the Classes of Subjects enumerated in this Section". Parliament alone, therefore, was granted the field of criminal law as a subject of legislative power.

It is not clear what matters were, in 1867 , thought to be aptly comprehended within the criminal law power. References to it were in fact rather perfunctory. ${ }^{\circ}$ Blackstone's description of criminal law as referring to ". . . a violation of public rights and duties due to the whole community, considered as a community"10 would probably have been considered adequate. Thus though the area was no doubt thought to be roughly definable, the ambit of the power, the uses to which it might be put, and the limitations to which it might be subjected, remained uncertain. That some novel legislation could thereby be comprehended was clearly evident; that not all legislation imposing a prohibition under a penalty could thereby be permitted to Parliament gained recognition in due course. But the limits of the area remained obscure. As Kenny stated years later, "Were only a rough general description to be attempted, this public mischief ought undoubtedly to be made the salient feature."11 It was soon seen to be too imprecise to provide real guidance.

Early decisions of both the Canadian courts and the Judicial Committee indicated that Federal legislation would be upheld under the criminal law power where such legislation was general in character and in relation to the safety of persons and property. ${ }^{12}$ The relevant features were the general application of the legislation, its mode of enforcement, and its address towards a clearly evident danger to the general public.

8 In Australia the States have power to lesislate in relation to the criminal law, and so has the Commonwealth in relation to Its territories. See Morris and Howard. Studies in Criminal Law (1964), introduction by Sir John Barry at Xvi - Xvil; in India the power is concurrent but certain serious crimes are reserved to Umion Competence. See The Constitution of India, Sched. VII List I item 93, List III, item 1

o See Levine and Stirling, Definitions: The Confused Early Years (1957), 15 Fac. L. Rev., at 13.

10 Blackstone, Commentaries, Bk. iv, at 4.

11 Kenny, Outlines of Criminal Law.

12 Russell v. The Queen (1882), 7 App. Cas. 829; Reg. v. Wason (1890), 17 O.A.R. 221; A.G. of Ontario v. Hamilton Street Railway Company, [1903] A.C. 524; Ouimet v. Bazin (1912). 46 S.C.R. 502; Ex. p. Wakabayashi, [1928] 3 D.L.R. 226. 
Necessarily, the reasoning developed partly from the known body of laws classified as criminal.

But there were limitations to this technique. Not all laws enforced by a penalty could be termed legislation in relation to the criminal law, since such a classification would deprive the provinces of the right to regulate matters essentially local and provincial by criminal penalty. In Reg. v. Wason ${ }^{13}$ the Ontario courts upheld a provincial statute forbidding certain frauds in supplying milk to dairy product manufacturers under penalty. The legislation was classified as legislation in relation to local trade rather than to matters of national concern. Conversely, in Doyle v. Bell ${ }^{14}$ it was held that Parliament could provide for the enforcement of its statutes by civil suit for a penalty without thereby rendering it legislation in relation to property and civil rights within the province. Generally, in this period, the Judicial Committee was content to hold that the British North America Act, 1867, reserved the criminal law in the widest sense of that term to the Federal Parliament, thereby neither helping nor hindering the lower courts in the process of interpretation. ${ }^{15}$

Difficulties arose so soon as limitations began to be set to other enumerated heads of Federal power. If Parliament could not regulate local trade under the commerce power, could it do so by negative restriction enacted under the guise of the criminal law power? The method of classification adopted-by subject-matter-compounded the problem. If rigid limitations were to be imposed and maintained it became necessary to enquire into what matters could properly be said to be criminal law. In respect of much legislation the solution was twofold. The first hurdle was to except the matter from another head of federal power (usually the commerce power) by treating its subject matter as one upon which each province could legislate locally. In addition it was excepted from the criminal law power, which did not suffer from the same restrictive interpretation as the commerce and general powers under sec. 91 , as not, by its nature, or subject-matter, falling within the ambit of criminal law. The sweep of the criminal law power was thereby to be restricted by being tied to an underlying definition of the subject matter of criminal law. In turn, this could have the effect of rendering the legislation as not in relation to the subject matter of criminal law, irrespective of the detriment to the public, actual or apprehended, which induced Parliament to act. So for example, in the Reciprocal Insurers case, ${ }^{16}$ the Judicial Committee held that Criminal Code provisions penalizing persons who undertook the underwriting of certain insurance risks without first obtaining a federal licence was an attempt to trespass into the forbidden field of property and civil rights within the province. The true character of the legislation ". .. is a measure regulating the exercise of civil rights". ${ }^{17}$ This approach is further exemplified by the Board of Commerce case. ${ }^{18}$ Parliament passed legislation to curb hoarding and black-market profiteering arising out of war-time shortages in certain commodities. Administration of the legislation was vested in the Board of Commerce which was given

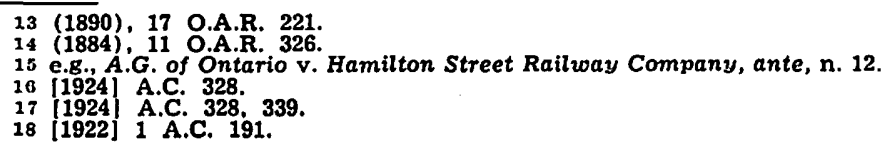


wide powers to prohibit accumulations of goods by non-traders; to compel the sale of articles at fixed prices; to regulate profits; to exercise powers over articles produced by a householder for his own use; and to enquire into individual cases without applying any principles of general application to the determination of what acts were culpable. The Judicial Committee, having held that the legislation could not be upheld under the commerce power, held also that it could not be supported under the criminal law power. That power enabled the Dominion to legislate ". . . where the subject matter is one which by its very nature, belongs to the domain of criminal jurisprudence. A general law, to take an example, making incest a crime belongs to this class. It is quite another thing, first to attempt to interfere with a class of subject committed exclusively to the Provincial legislature, and then to justify this by enacting ancillary provisions, designated as new phases of Dominion criminal law which require a title so to interfere as a basis of their application." 10

Had this construction prevailed, the situation could have been one of some difficulty. The idea of a domain of criminal law was not novel; it was in fact a summary of the result arrived at in certain nineteenth century English decisions relating to criminal law. It had, for example, been held that where matters were prohibited under a penalty, mens rea not being an element of the offence, the legislation was not truly criminal. ${ }^{20}$ Nonetheless, had Lord Haldane's construction endured, the Dominion might, for example, have been precluded from legislating in respect of some aspects of public welfare regulation, as, for example, commodity standards. ${ }^{21}$ It is not accurate to say that the Dominion could not have enacted new crimes. It is possible that, in respect of certain public welfare legislation, it would have been competent to legislate only where there was a possibility of clear danger to the public, and then perhaps, only where mens rea was an element of the offence."2 One could perhaps have expected a very cautious development by analogy to the known body of "criminal" law.

A further result of Lord Haldane's interpretation would have been to leave a wide field to the provinces. In Bedard v. Dawson ${ }^{23}$ it was held that legislation which tended to reduce conditions calculated to favour the development of criminal activities was competent to the provinces. In reliance upon this supposed provincial aspect, the provinces, among other matters, legislated to remove the evils of slot machines by providing that they could not be the subject of property in the provinces. The extent to which such an aspect still exists, and the areas in which it may operate are still an open question. ${ }^{24}$

The Judicial Committee resiled from Lord Haldane's interpretation in Proprietary Articles Trade Association v. Attorney-General of Can-

\footnotetext{
19) Id., at 198-199 (Viscount Ha'dane, L. C.).

$20^{\circ}$ e.g., Reg. v. Bradlaugh (1885), 14 Q.B.D. 667, Reg. v Bishop (1880), 5 Q.B.D. 259; and see generally, Stallybrass, The Eclipse of Mens Rea (1936), 52 LQ.R. 60.

1 Upheld as to food adulteration in Standard Sausage Co. v. Lee. [1934] 1 D.L.R. 707, in which case only Martin, J. A. expressly adverted to the possibility that such legislation might be upheld under the commerce power. See also Rex v. Perfection Creameries might be upheld under the commerce power. See also Rex v. Perfection Creameries

2.2 While, as Levine and Stirling, ante, $n$. 9. point out, the problem of definition was
never finally resolved, it seems a fair inference that many of the strict liability offences would have been classified as "quasi-criminal" and hence falling outside the ambit of the criminal law power.

23 [1923] S.C.R. 681.

24 See discussion post, especially with respect to the slot machine cases.
} 
$a d a .^{25}$ The case arose as a reference respecting the validity of the Combines Investigation Act, 1927, sec. 498 of the Criminal Code, 1927. By sec. 498 of the Criminal Code, every one who conspired in restraint of trade in such a way as unduly to limit competition, was made guilty of a criminal offence. The complementary Combines Investigation Act defined combine to mean a combine which had operated, or was likely to operate, to the detriment of the public. The Act, to be administered by a registrar, made provision for the conduct of enquiries into the operation of alleged combines. As a result of such enquiries, the combine could be prosecuted in the ordinary criminal courts at the instance of the Solicitor-General or the provincial Attorneys-General. The penalty on conviction was a fine not exceeding 10,000 or two years' imprisonment. ${ }^{26}$

In upholding the legislation as a valid exercise of the criminal law power, the Judicial Committee, in a decision delivered by Lord Atkin, enunciated several propositions of great importance. The idea that Dominion power was restricted to a "domain" of criminal law was firmly rejected. In a celebrated passage, Lord Atkin points out that the domain of criminal jurisprudence ". . . can only be ascertained by determining what acts at any particular period are declared by the State to be crimes, and the only common nature they will be found to possess is that they are prohibited by the State and that those who commit them are punished." Parliament is capable of enacting novel crimes, and prohibiting matters which it considers to be inimical to the public interest. The real contrast posed by Lord Atkin is between such valid, if novel matters and matters which are merely attempts to interfere with provincial jurisdiction and which are sought to be justified under the guise of criminal law in aid of what is, in substance, an encroachment. In the instant case, the legislation contained a general definition and a general condemnation, and violations were to be tried in the ordinary criminal courts. As Lord Atkin later pointed out, it is no objection to Federal legislation that it does in fact affect matters reserved to the provinces. While the provinces are not deprived by the plenary power of the Dominion of the right to affix sanctions to their own legislation, there is nothing to prevent the Dominion "... if it thinks fit in the public interest from applying the criminal law generally to acts and omissions which so far are only covered by provincial enactments."

Both the Judicial Committee and the Supreme Court have made it clear that Federal power is not unlimited: ". . . in a federal system, distinctions must be made arising from the true object, nature or character of such enactment". ${ }^{28}$ Such matters as the generality in application of the enactment, ${ }^{29}$ the evident character of the danger to the public, ${ }^{30}$ and past legislative history ${ }^{31}$ are, not surprisingly, still relied upon as

25 [1931] A.C. 310.

26 These provisions may be compared with those of the impugned Board of Commerce Act wherein a much wider element of administrative discretion was contemplated. See Murray, Economic Activity Under Criminal Law (1957), 15 Fac. L. Rev., at 25 .

27 [1931] A.C. 310, 317.

28 Lords Day Alliance v. A.G. of British Columbia, [1959] S.C.R. 497, 508 (Rand, J.); and see A.G. of British Columbia $v$ A.G. of Canada. (1937) A.C. 368 .

29 A.G. of British Columbia v. Smith (1965), 53 D.L.R. (2d) 713 .

30 Reg. v. Campbell, ante, $n_{\text {. }} 2$.

31 Canadian Federation of Agriculture v. A.G. of Quebec, [1951] A.C. 179; Industrial Acceptance Corporation v. The Queen, |1953| 2 S.C.R. 273; Regent Vending Machine Ltd. v. Alberta Vending Machines Ltd. and A.G. of Alberta (1956), 6 D.L.R. (2d) 144. 
aids in the process of classification. Furthermore, the Courts still attend to what they think are the essential concomitants of the criminal process. For example, while it is well established that Federal criminal legislation will not be struck down simply by reason of the novelty of the penalty imposed, ${ }^{32}$ it is not yet clear that Parliament could enforce criminal legislation by granting to a person damnified a civil right of action for damages. ${ }^{33}$ Nor is it yet clear under combines legislation that the power of Parliament extends to directing the dissolution of a merger, trust or monopoly per se, these not constituting criminal combines unless they had or were likely to operate to the detriment of the public. ${ }^{34}$ In the past, at any rate, a narrow view of the criminal process and the necessary limits of state interference has sometimes been taken. ${ }^{35}$

\section{PRESENT SCOPE OF THE CRIMINAL LAW POWER}

The question of what matters the criminal law power extends to thus remains one of some difficulty. It has been used both to uphold federal enactments, and as a negative head of assignment when impugning provincial legislation. The former phenomenon restricts provincial power since legislation though validly enacted from a recognized provincial aspect may be denied operation as a result of the paramountcy doctrine operating in the Dominion's favour. The latter is capable of denying altogether certain aspects as competent to the provinces. Here, it is proposed that three aspects of the problem be discussed. The first is the use of the power as a negative head of assignment, and, in particular, its use in the civil liberties cases. Secondly, a discussion is ventured with regard to the question of whether Parliament can legislate more amply under the criminal law power to support a specific piece of legislation than it could were it to employ another head of power which might equally have been prayed in aid; for example, the general power or the commerce power. Thirdly, a discussion of the provincial aspects, especially having regard to the doctrine of paramountcy, is attempted. Thereby, it is hoped to illuminate some of the problems in a most difficult field.

\section{USE OF THE CRIMINAL LAW POWER AS A NEGATIVE HEAD OF ASSIGNMENT}

The use of the criminal law power as a negative head of assignment first became evident in Reference re Alberta Statutes.":" There, one of the impugned bills, the Accurate News Bill, sought to provide that any newspaper which attacked government policy should be obliged to give equal coverage to any reply. While Duff, C. J. C., conforming to his previously expressed view of the type of governmental institutions sought to be embodied in the British North America Act," found the matter

32 Industrial Acceptance Corporation v. The Queen, [1953] 4 D.L.R. 369; Goodyear Tire and Rubber Company of Canada Limited v. The Queen, [1956] S.C.R. 303.

33 Direct Lumber Co. Ltd. v. Western Plywood Co. Ltd. [1962] S.C.R. 646, 648-50 (Judson, J.).

34 Goodyear Tire and Rubber Company of Canada Limited v. The Queen, ante, n. 32 in which the Court declined to pass upon the validity of that part of section 31 of the Combines Investigation Act which provides for the divestiture and dissolution of mergers, trusts and monopolies, essentially on the basis that it was arguable that this was not a sanction required for the purposes of the criminal law.

35 See Dowsett v. Edmunds. [1926] 3 w.W.R. 447; Rice v. Messenger (1929), 51 C.C.C. 147; and see the cautious approach of the Supreme Court in upholding the costs provisions of the Criminal Code in A.G. of Quebec v. A.G. of Canada, [1945] S.C.R. 600.

36 [1938] S.C.R. 100

37 See his judgment in the Persons Reference, [1928] S.C.R. 276, reversed sub. nom. Edwards v. A.G. of Canada, [1930] A.C. 124. 
to be one of national interest and importance and so not within provincial powers in relation to property and civil rights within the province, Cannon, J. preferred to rest his judgment on the basis that the legislation was essentially in relation to the criminal law as dealing with the offence of sedition. This narrower ground of decision was also chosen by a majority of the Supreme Court in Switzman v. Elbling. ${ }^{38}$ There, legislation making it illegal for an owner or occupier of a house to use it for the propagation of communism was classified by five judges of the Supreme Court as being in relation to matters affecting the security of the state and hence the criminal law. ${ }^{30}$ In Saumur v. City of Quebec ${ }^{40}$ legislation forbidding the distribution of literature in the streets without permission of the chief of police was said by Kellock, J. to impinge on the areas of criminal or blasphemous libel."1 The issue of a provincial aspect was raised and denied in the Switzman case. It was there argued on the basis of Bedard v. Dawson ${ }^{* 2}$ that the legislation was intended to remove conditions calculated to further the development of crime. Only Taschereau, J. acceded to the argument. It is indeed doubtful to what extent this is to be regarded as a valid provincial aspect at all. In Johnson v. A. G. of Alberta ${ }^{43}$ a majority of the court held that slot machine legislation passed professedly to deal with conditions calculated to favour the development of crime constituted a provincial trespass into the Federal field of criminal law. ${ }^{44}$ There is no doubt that legislation enacted with a view to the prevention of crime is competent to the Dominion. ${ }^{\text {s }}$ The issue is whether it is solely competent to it. And, of course, there is an area wherein it may be difficult to distinguish legislation as in relation to crime prevention, from legislation in relation to welfare, which is a matter for the province. ${ }^{46}$ Here, as Re Dunne ${ }^{47}$ discloses, the courts are prepared to uphold enactments containing welfare provisions under the criminal law power, provided that welfare is not the leading feature thereof.

Again, an assertion of the invalidity of provincial statutes on grounds they essentially relate to the criminal law occurs in the Lords Day Observance cases. Such legislation has long been held to be within Federal competence as a matter of criminal law. But the enforcement of days of rest, prima facie, can also bear a local aspect as a matter local or provincial. Here, distinct flexibility has been preserved. In Henry Birks \& Sons (Montreal) Ltd. v. City of Montreal and A.G. of Quebec, ${ }^{48}$ the court had to consider provincial legislation which enabled municipal councils to compel the closing of retail stores on certain feast days. The City, pursuant thereto, passed by-laws directing closure on certain feast days. The Appellant moved for a declaration that the by-law and enabling act were ultra vires as legislation in relation to the criminal law.

\footnotetext{
38 [1957] S.C.R. 285.

30 per Kerwin, C.J., Locke, Nolan, Cartwright and Fauteux, J.J.

40 [1953] 2 S.C.R. 299.

11 On this point see also Dionne v. Municipal Court of Montreal (1956), 3 D.L.R. (2d) 727, 735 (Scott, A. C. J.).

12 Ante, n. 23.

49 [1954] S.C.R. 127

44 See also Boyce v. The Queen (1959), 22 D.L.R. (2d) 555: De Ware v. The Queen [1954] S.C.R. 182; Reg. ex. rel. Barrie v. Stelzer (1957), 15 D.L.R. (2d) 280; Town of St. Leonard v. Fournier (1956), 3 D.L.R. 315; compare Millar v. The Queen, [1954] 1 D.L.R. 148.

45 Johnson v. The Queen, [1954] S.C.R. 127

40 Reg. v. Chief et. al. (1964), 42 D.L.R. (2d) 712, affords an example.

47 (1962). 33 D.L.R. (2d) 190 .

18 Henry Birks \& Sons (Montreal) Ltd. v. City of Montreal and A.G. of Quebec, [1955] S.C.R. 789 .
} 
It was held that the true character of the legislation was in relation to religious observance, its character being indicated by the fact that certain feast days had been singled out as occasions for closing. Historically, Sunday Observance legislation had pertained to the criminal law. Therefore, the legislation fell to be regarded as in relation to the criminal law rather than to hours of work. On the other hand, Lieberman v. The Queen $^{40}$ indicates that legislation in relation to hours of work is competent to the province. There, a provincial closing statute which provided for Sunday closing and dealt with the remainder of the week and working hours in general as well, was upheld. It is at least paradoxical, in the light of these decisions, that when the Supreme Court came to deal with the provisions of the Canadian Bill of Rights in relation to religious freedom, ${ }^{50}$ it chose to advance a secular justification for the Lord's Day Act ${ }^{51}$ in order to conclude that its provisions did not enforce the compulsory observance of Christianity upon the general public.52 The result may, as has been suggested, be justifiable as enforcing a common day of rest, but that is not the justification upon which the Act has usually been put; nor is it the reason why, historically, the statute has been enforced through the criminal law. ${ }^{53}$

It will be seen then, that in employing the criminal law power as a negative head of assignment, the court has nonetheless sought to leave a reasonable sweep to provincial jurisdiction. Although it may seem extreme to characterize provincial legislation relating to matters of religion as closely analogous to and therefore part of the criminal law relating to sedition or the libel group of offences, the classification is really a cautious means of excepting from provincial jurisdiction matters of national concern. Then, to except from provincial jurisdiction legislation professedly enacted with a view to crime prevention is surely not unjustified. The content which could have been read into such an aspect is uncertain and its implications are disturbing, as the occasions for its purported exercise disclose. It has not rendered urban renewal or slum clearance or general welfare legislation incompetent to the provinces. $^{54}$ It is still possible for the provinces to legislate on criminal matters, though perhaps only obliquely. On the whole, the position which has been reached has not resulted in any striking diminution of provincial powers. ${ }^{\text {ss }}$

\section{RELATION OF THE CRIMINAL LAW POWER TO OTHER FEDERAL POWERS}

Another aspect of the criminal law power which may prove disturbing

40 (1963), 41 D.L.R. (2d) 125.

501960 c. 44 , s. 2 .

51 R.S.C. 1952 c. 171

52 Robertson and Rosetanni v. The Queen, [1963] S.C.R. 651.

3 See Pauley, The Canadian Bill of Rights (1966), 40 H.L.J. at 36. But as the Court had made clear in the Birks case, Sunday Observance legislation had been upheld as a criminal provision relating to the profanation of the Sabbath. See also Lords Day Alliance v. A.G. of Manitoba, [1925] A.C. 384.

54 See Reg. v. Chief, ante, n. 46.

s5 Certainly, the process of construction by analogy employed in these cases is less destructive of provincial powers than would be the adoption of Rand, J.'s citizenship thesis advanced in Winner v. S.M.T. (Eastern) Ltd. and A.G. of New Brnuswick, [1951] S.C.R. 887. Roncarelli V. Duplessis (ISstern) L.R. and A.G. of New Brnuswick, [1951] S.C.R. 887; Roncarelti v. Duplessis, [1959] S.C.R. 121; and recently by the Supreme Court in MacKay v. The Queen, [1965] S.C.R. 798. For an early study of the implica-
tions of this development, see Price, Mr. Justice Rand and the Privilieges and Immunittions of this development, see Price, Mr. Justice Rand and the Privilieges and Immunit-
ies of Canadian Citizenship (1958), 16 Fac. L. Rev. 16. For another appreciation of its possibilities, see Beetz. Les Attitudes Changeantes du Quebec a I'endroit de la Constitution de 1867, in The Future of Canadian Federalism (ed. Crepeau and MacPherson, 1965) at 132-133. 
is the possibility that the courts will permit the Federal parliament to do under the criminal law power, things which could not be done under directly apt enumerations. The danger is one to which the courts have in the past been alert. In the Margarine case $^{56}$ the Judicial Committee was faced with a reference to determine the validity of section 5 (a) of the Dairy Industry Act which prohibited the manufacture, sale, and importation into Canada of oleomargarine. In part it was sought to uphold the legislation as in relation to the criminal law. Former statutes dealing with the subject matter had declared margarine to be injurious to health. The legislation in question was not cast in those terms. After determining that the legislation could not be upheld under the commerce power as being in relation to the regulation of individual forms of trade and commerce within the province, the Judicial Committee proceeded to hold that the legislation was not in relation to the criminal law. It was, in pith and substance, legislation for the protection of the Canadian dairy industry. While the combines cases could be upheld as safeguarding the public against the evil consequences of fetters on free and equal competition, the instant case disclosed no more than a preferring of one local trade over another. In general, it seemed that the courts might be more ready to discern a federal aspect where the legislation professed to rely on the criminal law power rather than the commerce power or the general power. But the limitation that the legislation must not in substance be in relation to a provincial subject-matter of jurisdiction remained. Conceding that it could act as a general prohibition on certain types of trading activity, thereby limiting the ambit of provincial competence, the issue yet remained of determining when a prohibition could be said to be so minutely prohibitory as to constitute negative regulation. ${ }^{57}$

Recent combines legislation raised these issues in an acute form. By a 1960 amendment to the Combines Investigation Act, it is now provided that no dealer shall, directly or indirectly, by agreement, threat, promise or any other means, require, induce or attempt to require or induce any person to re-sell an article or commodity at a price not less than a minimum price, specified by the dealer or established by agreement. The constitutional validity of these provisions was dealt with by the Ontario Court of Appeal in $R$. v. Campbell. ${ }^{5 s}$ A majority of the court held the legislation to be a valid exercise of the criminal law power. Whilst recognizing that the Federal Parliament is limited by the colourability doctrine, the Court was prepared to make an initial assumption in favour of validity and to hold that the statute had, as its object, the safe-guarding of the public against what Parliament regards as "... the evil consequences of the commercial activities therein described." The effect of the practices struck at was to impose restraints upon free and equal competition, ". . . a practice which, in the opinion of Parliament, ought to be suppressed in the public interest."io These considerations, in view of traditional doctrine, cannot surely foreclose the issue. Much legislation, enacted under the commerce power could surely have been

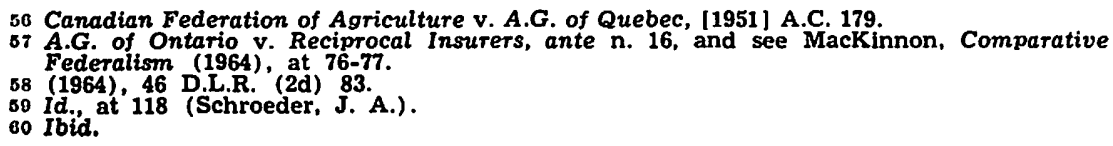


said to strike at evils envisaged by Parliament, which ought to have been suppressed in the public interest. Nor, on inherited doctrine, could it be said that Federal legislation would be held valid because only Parliament could adequately cover the field. In the past, such legislation had been struck down. ${ }^{11}$ But these issues were not adequately dealt with by the majority of the court.

The dissentient minority, Porter, C. J. O., with whom Kelly, J. concurred, adopted a conserative stance, holding that the legislation was essentially in relation to contracts of trade within each province and therefore in relation to property and civil rights within the province. No presumption was made in favour of the legislation; it was not assumed that resale price maintenance was harmful to the public. The Dominion, they held, must restrict itself to the prohibition of trade practices which are harmful to the public. Earlier combines legislation was said to meet the test; first because it was cast in terms of prohibiting combines whose activities were harmful to the public, and secondly, because the findings of a 1935 Royal Commission on Price Spreads seemed to establish that certain restraints on competition were inimical to the public interest. $^{62}$

The dissentient minority clearly adverted to some of the difficult issues in the field. It held that the Dominion cannot, by legislating under the criminal law power, go farther than it could have done under the commerce power. Clearly, a scheme of negative restriction can become sufficiently specific as virtually to amount to positive regulation. This difficulty has long been recognized. ${ }^{03}$ Therefore, if the Dominion is to intrude further into provincial fields than it could under the general power or the commerce power, some criminal aspect must be found to justify the result. It is in its indication of what matters might suffice to found a criminal aspect that the minority to some extent proceeds on an illusory basis. In the light of previous authority, it is difficult to see how a Parliamentary intrusion could be upheld on the basis of a declaration that the impugned practices were harmful to the public. It seems unrealistic to hold that Parliament's earlier ventures into the fields of hoarding and insurance reflected mere caprice. Moreover, it must surely follow from prior authority that the element of detriment to the public will not necessarily validate legislation under the criminal law power, because if so, it would surely validate such legislation under other enumerated heads of power. This, however, has not been permitted. ${ }^{64}$ It must surely follow that as respects much legislation, harm to the public is not enough to bring it within the scope of the Dominion Parliament; the matter must also be viewed in the perspective of maintaining a balance between federal and provincial powers. In delimiting the boundaries of the criminal law power the minority were reasoning conservatively, by analogy from the known body of criminal law. Nor were the majority in this respect much more venturesome. The case could have raised wide issues respecting the ambit, not only of the

61 See in particular. A.G. of Canada v. A.G. of Ontario, [1937] A.C. 355.

62 (1964), 46 D.L.R. (2d) 83, 98 (Porter, C. J. O.).

63 A.G. of Ontario v. Reciprocal Insurers, ante, n. 16. A similar phenomenon has caused considerable difficulty in the United States since Baker v. Carr (1962). 369 U.S. 186; See Baker, "Representative Equality" in Dietze (ed.) Essays on the American Constitution (1964), at 23 et. seq.

o4 For a discussion, see Mackinnon, ante, at 77-78. 
criminal law power, but of the commerce power as well. It is perhaps an indication of judicial conservatism and restraint that these issues were not squarely faced.

\section{EFFECT OF THE DOCTRINE OF DOMINION PARAMOUNTCY ON PROVINCIAL POWERS}

Finally, some light on the present temper of the courts is shed by an examination of the fate of the doctrine of Dominion paramountcy as applied to legislation upheld as legislation in relation to the criminal law.

Here, the most striking examples occur inter alia, with respect to legislation dealing with gaming, and motoring offences. We may first consider the gaming cases. Following Bedard v. Dawson, ${ }^{63}$ the Provinces, relying on the assertion that the provinces could competently legislate in such a manner as to eradicate conditions favouring the growth of crime, passed legislation outlawing slot machines. Provisions relating to gaming were also contained in the Criminal Code. ${ }^{66}$ Generally, the scheme of provincial enactments was to render slot machines incapable of ownership within the province and to provide for their forfeiture by courts of summary jurisdiction. The Criminal Code made the use of such machines unlawful and provided penalties for conviction, one of which was forfeiture of the machine. ${ }^{67}$ Its method of attack was to make user of a slot machine prima facie evidence that the premises on which user occurred were used as a common bawdy house. Early decisions upheld the validity of provincial legislation. ${ }^{68}$ In Rex v. Stanley, ${ }^{69}$ the Alberta Appellate Division was prepared to say that even had Parliament made ownership or possession of the machines an offence, the legislation would still have been competent to the Province as legislation designed to suppress conditions tending to favour the development of crime.

A change of opinion occurred in Johnson v. Attorney-General of $A l$ berta, a case involving the validity of the provincial Slot Machine Act. ${ }^{70}$ The Alberta statute and the Criminal Code defined "slot machine" in substantially similar terms by reference to the element of chance in the result of user. The Criminal Code created an irrebutable presumption that the place on which such a machine was found was a common gaming house for the keeping of which, penalties were provided. The Code further provided for seizure and forfeiture of such machines, empowering courts of summary criminal jurisdiction to order forfeiture. The provincial statute provided that slot machines should be incapable of ownership in the province, or of being the subject of property rights therein, authorized the justices to grant warrants to the police to search premises for such machines, and gave the justices power to order confiscation. A majority of the court held the provincial legislation to be invalid as a direct attempt to encroach upon the forbidden field of criminal law. Rand, J. in addition, found that Parliament had occupied the field, and that the provincial provisions being duplicative, they would tend to confuse enforcement of the Code provisions. Locke, J.,




basing his judgment both on the occupied field and colourability doctrines, held that the legislation not only duplicated Code provisions, but was enacted from the same aspect; distinguishing the legislation in Bedard v. Dawson ${ }^{71}$ as enacted from a local aspect and in relation to local objects, he stated that valid legislation which tends to prevent the existence of conditions which may foster crime is usually directed towards such local objects as slum clearance projects. Cartwright, and Kellock, J. J. found the legislation to be in relation to criminal law, constituting thereby an intrusion into a forbidden field. The test of substantial duplication has been applied by provincial courts with respect to similar legislation. ${ }^{22}$ In the result, two propositions seem to be established; first, that the provincial aspect spoken of in Bedard v. Dawson does not permit the province so to legislate as merely to improve on existing Federal provisions, thereby rendering the crime prevention aspect, as such, dehors provincial authority; secondly, that where there is a possibility of concurrent powers operating, provincial legislation which in effect duplicates Federal legislation cannot stand. ${ }^{73}$

This has not, however, meant the eclipse of provincial legislative powers. Their continued vitality in the field of motor vehicle regulation is a matter of note. Here, one must turn first to an earlier decision of the Supreme Court, Provincial Secretary of P.E.I. v. Egan. ${ }^{74}$ The provincial Highway Traffic Act provided that the motor vehicle driver's licence of any person convicted of driving under the influence of drink or drugs should forthwith be suspended for a period of twelve months on a first offence, and that no licence should be issued to such person during any such period of suspension. The then Criminal Code provided that on such a conviction, the court could in addition to any other punishment provided, prohibit the accused from driving a motor vehicle anywhere in Canada during any period not exceeding three years. The respondent, who was convicted, but whose licence was not suspended under the Code provisions, applied to the Provincial Secretary for a driver's licence. The application having been refused under the authority of the provincial statute, the accused brought an action alleging that the provincial statute was ultra vires as in relation to the criminal law. Duff, C. J., found that the legislation was competent to the province, the relevant aspect being provincial responsibility for regulating highway traffic, including the conditions on which and the manner in which vehicles could be used, in the interests of the general public. Provided that the prohibition against driving was made for the purposes of highway regulation, it was competent to the province to use the fact of conviction as a ground of licence suspension. Such a suspension was not to be looked upon as an additional penalty. The entire court stated that licence suspension is not a punishment; it is a civil disability. Then, adverting to the doctrine of paramountcy, the court held that the operation of the two enactments was not identical. The provincial act imposed a disability only within the province; while an order made under the Code was national in scope and operated independently of any licensing provisions in provincial legislation. It could not, therefore, be said that

i1 \1923| S.C.R. 681.

72 Regent Vending Machines Ltd. V. Alberta Vending Machines Ltd. and A.G. of Alberta (1956), 6 D.L.R. (2d) 144.

i3 See authorities cited at ante, n. 44.

i4 [1941] S.C.R. 386. 
the provincial legislation was repugnant to the Criminal Code. It may be noted that the Court confined repugnancy within a narrow compass; it did not lay down a general rule that provincial legislation is to be overborne in cases where the Dominion seems to have intended to occupy the field.:5 Repugnancy is predicated on the narrower ground of there being identity of substance between the two pieces of legislation considered.

This has proven to be a fertile area for provincial jurisdiction. The Supreme Court has tended to apply the paramountcy doctrine in a distinctly limited fashion so as to allow considerable freedom of enactment to the provinces. In four leading cases, Federal legislation has been narrowly defined to this end. Reference re the Validity of Section 92 (4) of the Vehicles Act, 1957 (Sask.) ic posed the issue of conflict between a section of the Criminal Code which provided that, in relation to proceedings for drunken and impaired driving offences under the Code, the results of chemical tests were admissible in evidence, but that no person could be compelled to furnish such evidence. Provincial legislation empowered the Highway Traffic Board to suspend or revoke the operator's licence of any person who, inter alia, refused to comply with a request to the taking of a specimen of his breath. In finding that no repugnancy between these provisions existed, a majority of the Court held that the provincial legislation did not create a legal obligation on the part of the licence holder to comply with the request. The consequences of refusal did not affect the nature of the accused person's rights. And the legislation was necessary from the provincial aspect of highway safety. Even if in effect a statutory compulsion were created, it was created only for provincial purposes. Read against the evidentiary rule that the immunity from incriminating evidence is confined to that which bears a testimonial character ${ }^{77}$ the view taken of the nature of compulsion seems distinctly arbitrary. The failure to perceive repugnancy is at least surprising. As Cartwright, J. dissenting, stated, the direct effect of the provincial enactment was to nullify within the province the protection given by the Criminal Code. The scope given to the repugnancy doctrine was narrow indeed. Seemingly, provincial legislation would only have been invalid had it purported to oblige a person to give a test for Code purposes, in which case the legislation would be in relation to criminal law and so ultra vires. That it might have this effect, was held insufficient to bring it within the paramountcy doctrine. It remains doubtful what the position would be were a penal sanction attached by Provincial legislation to a refusal. is It is hard to believe that in such a case the paramountcy doctrine would not apply against the province. If so, the Court's decision extends provincial competence by an unedifying resort to semantics.

i5 Compare the Australian position as stated in Clyde Engineering Co. Ltd. v. Cowburn (1926), 37 C.L.R. 466; Stock Motor Ploughs Ltd. v. Forsyth (1932), 48 C.L.R. 128. In which much broader "covering the field" doctrine has been adopted, essentially for the same reasons as governed the Supreme Court's decision in the Johnson case.

76 [1958] S.C.R. 608.

77 A.G. of Quebec v. Begin, [1955] S.C.R. 593.

78 This was a principal ground relied on by Fauteux. Taschereau, Abbott. Judson, and Rand, J. J., holding that the provincial legislation left the accused a faculty to refuse to comply. On the reasoning of Rand. J. at any rate. It seems clear that were the accused required under provincial criminal penalty to submit to a test, there would exist an effective compulsion inconststent with the Code provision against "requiring" a sample to be given. 
A similar narrow view of the paramountcy doctrine appears in other cases. In Smith v. The Queen ${ }^{70}$ three judges speak of the paramountcy doctrine operating where there is conflict in the sense that ". . compliance with one law involves breach of the other." In O'Grady v. Sparling ${ }^{80}$ seven judges refused to find repugnancy between the criminal negligence provisions of the Criminal Code ss 191 (1) and 321 (1) and the careless driving section of the Manitoba Highway Traffic Act on the basis that the two sections struck at different types of conduct and for different purposes. Thereby, despite previous Supreme Court decisions on the matter, inadvertent manslaughter was removed from the corpus of Canadian criminal law. ${ }^{\mathrm{S1}}$ The issue of paramountcy is said to be whether both items of legislation can live together and operate concurrently. In the O'Grady case the provisions were said to deal with different subject matters and to deal with different purposes. The former conclusion involves a distinctly narrow view of the intended subject matter of the manslaughter section; the latter is not dispositive for the purposes of paramountcy since measures enacted from different aspects can conflict. ${ }^{82}$ At all events, the purposes were surely identical; to promote the safety of the public on the highway. The same theme appears in Stephens v. The Queen, ${ }^{\times 3}$ another highway case involving competing Highway Traffic Act and Criminal Code provisions respecting the duty to stop and render assistance to persons resting on persons in charge of a vehicle involved in an accident. Again, finding no repugnancy in the sense above discussed, both pieces of legislation were upheld. The wider test favoured in other jurisdictions; of determining repugnancy by deciding whether Parliament intended to cover the field appealed to only a minority of the Court. The same analysis again appears in the judgment of Spence, J. in Mann v. The Queen ${ }^{* 4}$ in which the provincial offence of careless driving and the Code offence of dangerous driving were in issue. The legislation, it was said, overlapped, but could operate concurrently. In thus adopting a narrow test of repugnancy the Court seems to have been influenced by a felt need to preserve the powers of the provinces. As Fauteux, J. stated in the Mann case, the criminal law power may not be so extended as to lead to ". . . the gradual and eventual absorption of the provincial regulatory power. Indeed, both these powers must be rationalized in principle and reconciled in practice whenever possible." 85

But this consideration, while real and undoubtedly valid, does not account entirely for the trend of decision. A considerable measure of control would remain were the provinces restricted to legislation in respect of lesser motoring offences, rates of speed, rules of the road, and vehicle equipment and fitness. The fact that Parliament saw fit to impose liability for careless driving, ${ }^{\text {, }}$ failure to remain at the scene of an accident $^{87}$ or motor manslaughter ${ }^{88}$ might well be taken as sufficiently




indicative of an intention to occupy this part of the field entirely. ${ }^{89}$ Especially with regard to the careless driving section, the fact that paramountcy problems would arise was foreseen not only in academic circles, but presumably in the Department of Justice as well. ${ }^{90}$

In its recent decisions, the Court seems to be heavily influenced by the view that certain subject matters are peculiarly apt subjects for provincial regulation. It would not be surprising to find that conclusion reached in respect of highway safety, and not reached, for example, in respect of gaming. Highway construction and use is primarily a matter of provincial concern and one for which provincial governments are answerable to the electroate which may well not be impressed by arguments advanced on the basis of a divided jurisdiction. Developments in the field occur with considerable rapidity. Legislation can probably be passed more expeditiously at the local level, and administrative discretion is probably better exercised there. ${ }^{91}$

Like considerations probably apply in the field of securities regulation, in the absence of the adoption of some regulatory scheme by the federal parliament. The result of decisions in the field has been to create the possibility of interprovincial control over securities trading by the use of complementary provincial legislation, and of the necessity for control there can be little doubt.92 Some of the provincial enactments in the field are clearly fraud-oriented. ${ }^{93}$ In Smith v. The Queen ${ }^{04}$ the validity of the offence provisions of one such enactment was upheld, the Court finding that there was neither trespass nor repugnancy to the existing provisions of the criminal law. The narrow ambit given to the repugnancy doctrine; whether there is conflict in the sense that obedience to one provision involves breach of the other, surely reflects a desire to preserve the integrity of an administrative scheme. Similarly, recent decisions on provincial investigatory provisions under the Securities Acts bear this construction. It has been held for example that provisions which found jurisdiction in the Securities commissions to investigate the affairs of a person or company where it appears probable that such person or company has committed an offence under the Criminal Code, are competent to the provinces. Such legislation has been classified as not in relation to the criminal law, but as part of the administrative machinery required to enforce the Securities Acts. ${ }^{95}$

On the other hand, in Re Batary's Prohibition Application, ${ }^{06}$ provin-

89 Dean Lederman for example, writing before the decision in the Mann case, argued that in the light of the Code provision relating to careless driving, the provincial provisions had become merely duplicative and hence suspended and inoperative. See provisions had become merely duplicative and hence suspended and inoperative. See The Concurrent Operation of Federal and Provincial Laws in Canada, in The Courts and the Canadian Constitution, (ed. Lederman, 1964) at 217-8. In the light of developHooper, Dangerous Driving (1966), 9 Cr. L.Q., at 41.

90 Macdonald, Careless, Negligent Reckless, Operation of Motor Vehicles (1962), 6 Can. Bar J., at 122.

01 Mann v. The Queen, ante n. 84; Reg. v. Yolles (1959), 19 D.L.R. (2d) 19.

92 Reg. v. W. MacKenzie Securities et. al. (1966), 56 D.L.R. (2d) 56; and see Gregory \& Co. Inc. v. Quebec Securities Commission, [1961] S.C.R. 284.

93 Securities Act, 1955 c. 64 (Alberta); Securities Act, R.S.S. 1965 c. 396: 1962 c. 55, 80 (Brit. Col.) R.S.M. 1954 c. 237, ss. 2(d) 20 (1); R.S.N.S. 1954 c. 261 ss. 2(c), 38: R.S.N.B. 1952 c. 205 , ss. 1 (d), 36; R.S. Nfld. 1951 c. 1939, ss. 2(c), 38; R.S.Q. 1964 c. 274, 35, 88, 89 .

O4 [1960] S.C.R. 776

95 International Claim Brokers Ltd. v. Kinsey and Attorney-General of British Columbia (1966), 55 W.W.R. 672; Re Williams and Williams (1961), 29 D.L.R. (2d) 107. That such provistons can perform a criminal discovery function appears from Rex $v$. Simpson and Simmons, [1943] 3 D.L.R. 355, wherein books and documents produced before a commissioner by statutory compulsion were seized from the commissioner's possession by search warrant and used in subsequent criminal proceedings.

88 (1965), 51 W.W.R. 449 . 
cial legislation enabling an adjourned inquest to be reopened and the witness examined as to a death for which he was concurrently standing trial was struck down. The Court adopted the view that a person could not be made a compellable witness against himself in criminal proceedings, that a coroner's inquest is a criminal proceeding, and that provincial legislation purporting to compel an accused to give evidence against himself was in relation to the criminal law and therefore ultra vires the province. What this seems to imply is that legislation in relation to criminal discovery is incompetent to the province. This is not entirely so however since presumably any person may be called as a witness provided that he has not been charged with a relevant offence. Furthermore, it is well-recognized in the securities field for example, that investigatory provisions can be made to serve a criminal discovery function. ${ }^{97}$ The possibility is enhanced where the investigation is into a suspected violation of the Criminal Code. Analytically, it is difficult to distinguish such legislation from the impugned provisions of the Coroners Act except upon the rather superficial footing that there a person had already been charged whereas the provisions of the Securities Acts do not in terms provide for the examination of a person or company already charged. Similarly, there seems a criminal discovery aspect present in legislation penalizing persons for failure to submit to a breath test, the results of which may well be led in evidence in subsequent criminal proceedings.

In other areas where similar considerations apply recent decisions disclose a sensitivity to issues of legislative power. As has been noted judicial doubts have been expressed about the validity of extended combines legislation. ${ }^{98}$ Provincial courts have sought to ensure a wide ambit to provincial legislation in respect of welfare functions. Thus the Manitoba Child Welfare Act provisions relating to the duty to maintain children have been held not to be inconsistent with the more limited provisions of the Criminal Code. ${ }^{09}$ The Juvenile Delinquents Act which contains welfare features ${ }^{100}$ has provoked dissenting judgments classifying the legislation as in relation to child welfare. ${ }^{101}$ Seemingly, the recent trend of decision contains tacit value judgments regarding provincial occupancy of certain fields which to some extent influence not only the initial question of classification, but also the development of the paramountcy doctrine. Permissive attitudes towards provincial legislation, possibly susceptible of classification in whole or in part as in relation to criminal law seem evident, particularly in fields where the provinces have some plausible title to intervene, and in which provincial coverage has become fairly comprehensive. In the result, a movement or trend towards a functional concurrency in the criminal law field seems to be occurring.

It is difficult to predict future developments with any confidence. The old limitations receive verbal obeisance, but their influence is being eroded. In some areas the courts are prepared to say that doubtful legislation is in relation to criminal law, rather than invoking the more

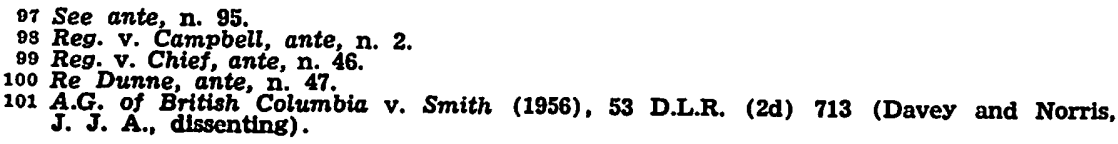


cautious ancillary doctrine. Yet though this is no doubt welcome, if confined to the criminal law power, its effects could be distorting, not only in relation to the balance of power as such, but also in relation to our legal and procedural structure. ${ }^{102}$ Quite possibly for example, the criminal law will be used as a dominant feature in schemes where sound policy might otherwise dictate that it should be assigned to an ancillary role. ${ }^{103}$ The same consequences could ensue from an unduly permissive attitude towards provincial legislation. Impaired enforcement and the possibility of confusion led to the striking down of provincial gaming legislation; the same dangers could become evident elsewhere. Yet unless doctrines of interpretation under the British North America Act are accorded a fundamental judicial review, it is difficult to see how these consequences can be avoided. It seems unlikely that any return to the old a priori limitations will take place. It may be that the future will see a general adoption of the aspect doctrine in respect of all the heads of power in sections 91 and 92 . Certain recent decisions bear this construction. ${ }^{104}$ Given a narrow application of the paramountcy doctrine, this will not detract substantially from provincial powers, unless indeed, Parliament proceeds to occupy certain fields more vigorously than it has hitherto done. But at present such measures might well be regarded as politically unacceptable. Hence it would seem that one must accept a gradual development towards concurrency such as is now occurring, accepting the resultant anomalies as part of the price of cohesion.

102 See Hooper, ante, n. 98.

$103 \mathrm{eg}$. the field of Combines regulation wherein, for example, both the United Kingdom and Australia have decided not to enforce the legislation by a primary use of the criminal law.

104 Mann v. The Queen, ante, n. 84: National Capital Commission v. Munro (1966), 57 D.L.R. (2d) 753 . But even assuming greater recourse to the aspect doctrine, it must be remembered that those areas where the courts have found an office for the general head of power under 5 . 91 have been fairly closely defined. 